\title{
Geophysical investigations offshore East Greenland - Project NAD
}

\author{
M. S. Andersen, H. C. Larsen, J. B. Risum and L. Thorning
}

The objective of project NAD is to map the continental margin of East Greenland, using high sensitivity aeromagnetic surveys and multichannel seismic reflection and marine gravity and magnetic surveys, and to prepare a preliminary petroleum geological assessment of the region on the basis of all the available data.

The aeromagnetic surveys were carried out during 1979 (Larsen \& Thorning, 1980). Marine geophysical surveys are planned for 1980, 1981 and 1982 (Risum, 1980).

During 1980 a total of $2610 \mathrm{~km}$ of marine geophysical data were collected and the processing and interpretation of the aeromagnetic data acquired in 1979 was continued.

\section{Project EASTMAR}

The compilation of the aeromagnetic data collected in 1979 (Larsen \& Thorning, 1980) was completed during 1980 by Aero Service Division, Western Geophysical Company of America, Houston. A GGU geophysicist (Thorning) participated in the early compilation, and parameters to be used were agreed upon. The final products are flight track maps, total field contour maps, second vertical derivative contour maps of some areas, and CalComp profiles of all corrected profiles with accessory data (fig. 19). The scale of the maps is 1:250 000 (with photo-composites scale 1:500 000) and the scale of the CalComp profiles is 1:125 000. The analog data in the form of maps and profiles were delivered to GGU in the period from January to April 1980. The delivery of the digital data in GGU format was unfortunately delayed until September 1980 due to a computational error by Aero Service in the conversion. At the time of writing the digital data are being entered into GGU's aeromagnetic data base, and will be ready for computer aided interpretation (Thorning, 1980) by February 1981.

The high quality of the new data has been confirmed, and many striking and reliable features suitable for geological and geophysical interpretation are present in both the old and the new data (see also Larsen \& Thorning, 1980). The aeromagnetic maps have been utilised in the planning and execution of the 1980 seismic work. On the basis of the analogue data, a study of the oldest oceanic anomalies between $60^{\circ}$ and $70^{\circ} \mathrm{N}$ has been carried out (Larsen \& Jacobsen, submitted), indicating that the major part of the outer shelf north of about $65^{\circ} \mathrm{N}$ rests on oceanic basement formed along the northward extension of the early Reykjanes Ridge.

\section{Marine geophysical data acquisition}

The 1980 seismic survey operations were contracted to Western Geophysical Company of America, London, and carried out using the R/V Western Arctic. During the period from 13 th August to 27 th September a total of $2610 \mathrm{~km}$ of seismic, gravity and magnetic data 


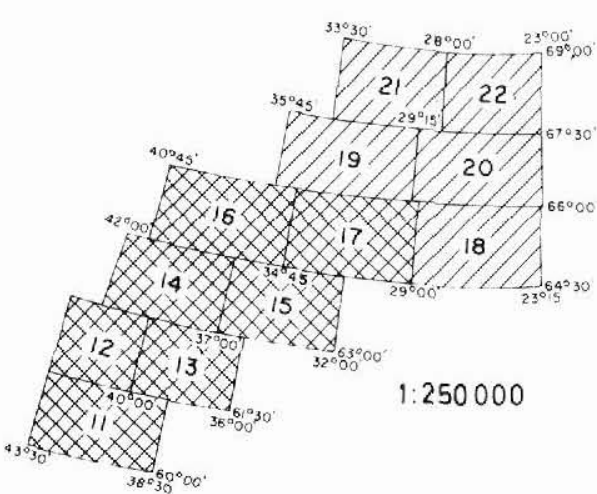

SOUTH AREA

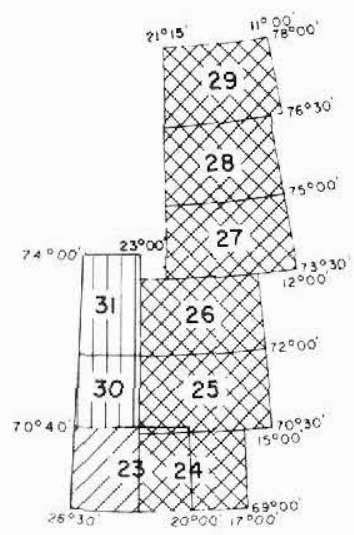

NORTH AREA
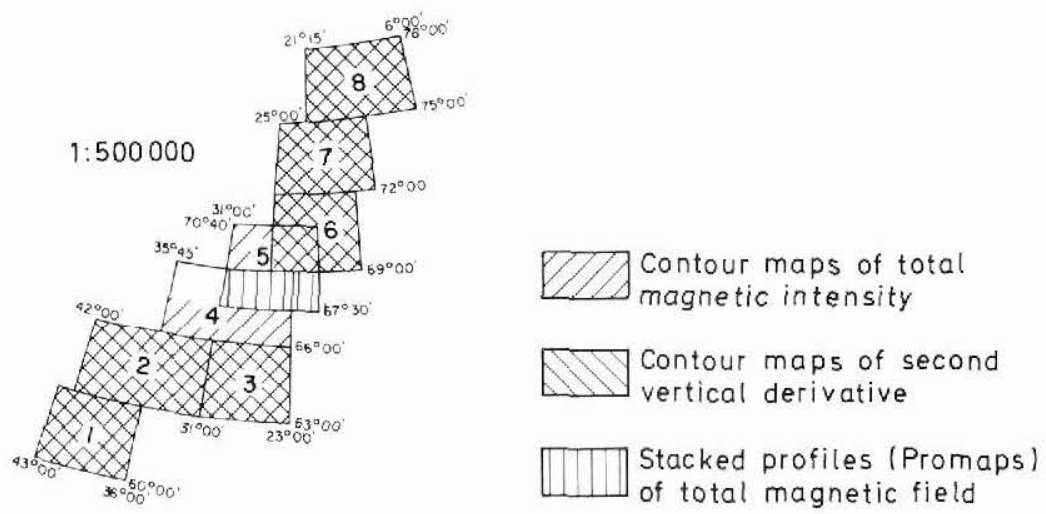

Fig. 19. Schematic summary of map sheets showing the different types of magnetic data produced offshore East Greenland.

were collected, and refraction data recorded on 19 sonobuoys (fig. 20). Of this, $74 \mathrm{~km}$ were recorded using maxipulse as the seismic energy source and a shooting interval of $25 \mathrm{~m}, 974$ $\mathrm{km}$ were recorded with maxipulse and a shooting interval of $50 \mathrm{~m}$, and the remaining 1562 $\mathrm{km}$ were recorded using Western Geophysical's new 905 cubic inch high pressure airgun array as energy source and a shooting interval of $25 \mathrm{~m}$. Quality control during the survey was exercised on behalf of GGU by a consultant from Exploration Consultants Ltd. Three GGU geophysicists participated in the survey (Andersen, Risum \& Thorning).

During the survey period weather conditions were good. Equipment problems were the main reason for lost production. This survey was the first survey for $\mathrm{R} / \mathrm{V}$ Western Arctic as a geophysical vessel and problems were experienced with deployment of both the cable and the airgun system. Maxipulse was therefore used as an alternative to airguns for part of the survey.

Seismic recording was done with a DFS V seismic recording system and a $3000 \mathrm{~m}$ 


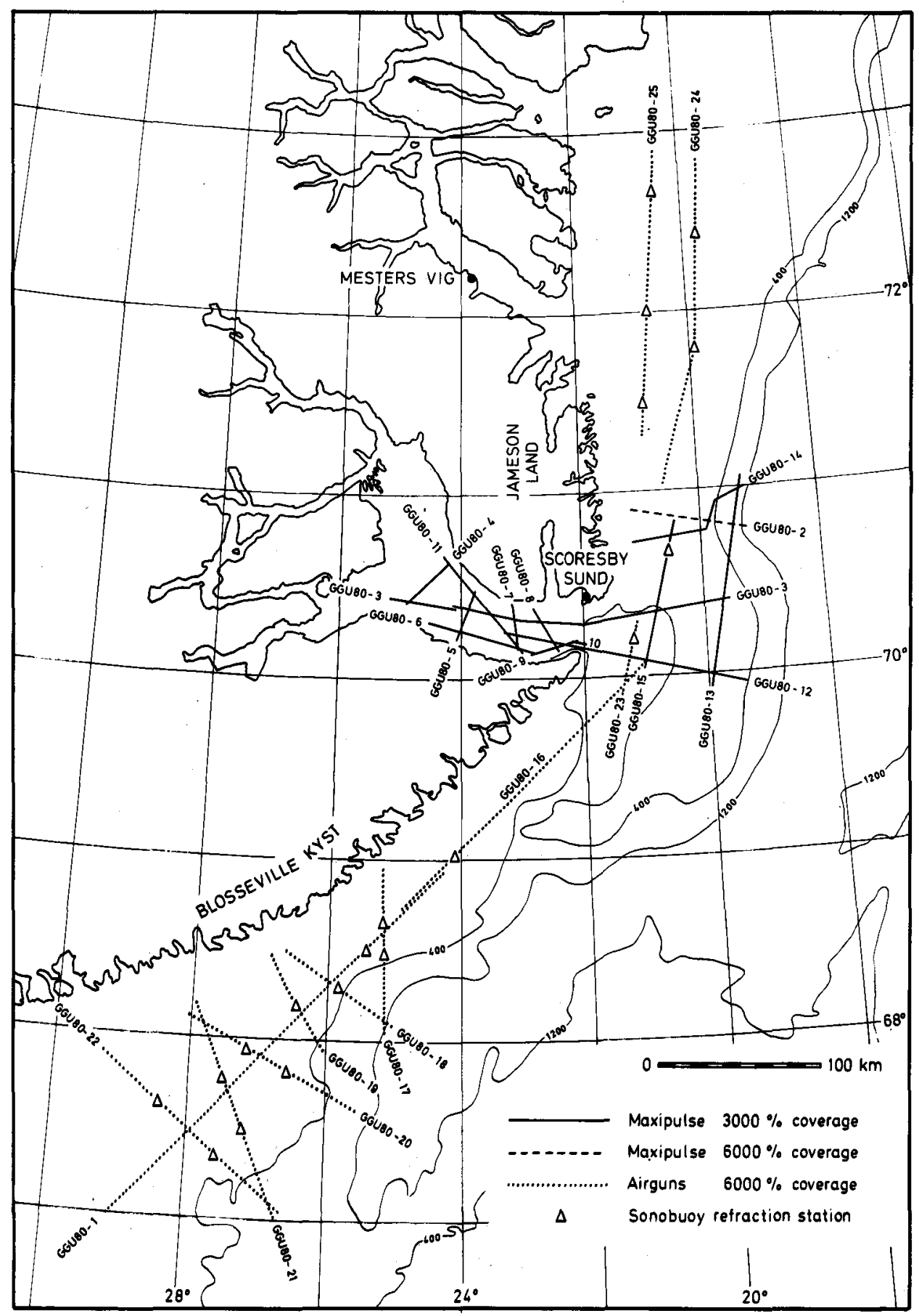

Fig. 20. Seismic lines acquired within project NAD during 1980. 
streamer cable with sixty overlapping groups each $75 \mathrm{~m}$ long, and with $50 \mathrm{~m}$ intervals between group centres. Gravity was recorded using a LaCoste \& Romberg marine gravimeter, and magnetic data were recorded using a Geometrics 801/803 marine magnetometer/gradiometer. Positioning was done by satellite with doppler sonar and Loran C integrated.

The Danish Hydraulic Institute (DHI) was contracted to provide ice reconnaissance on a regional scale for the duration of the survey using a Cessna 402 airplane. This operation was based on Reykjavik in Iceland. Information on ice conditions was transmitted to the survey vessel by facsimile via the Danish Meteorological Institute. Short range ice reconnaissance in the vicinity of the survey vessel was carried out using a Hughes $500 \mathrm{D}$ helicopter based on the vessel. The helicopter also proved important in the transport of the necessary personnel to and from the survey vessel. The helicopter was chartered by GGU from Greenland Air Charter.

The lines originally planned were modified prior to the survey in the light of the information derived from the aeromagnetic surveys (see also Larsen, 1980), but also in order to minimise time spent in transit during line changes. During the survey, lines occasionally had to be changed due to ice conditions.

\section{Seismic data processing}

Western Geophysical Company of America, London, was selected to process the seismic data. The processing will include but not be limited to demultiplexing, true amplitude recovery, editing, deconvolution before stack, velocity analyses, normal move out correction, CDP stack, deconvolution after stack and time variant filtering.

\section{Availability of data}

Project NAD is planned to continue until mid 1983 when the release of digital data, aeromagnetic maps, processed seismic sections, and various other products will commence. However, results and parts of the data may be published during the course of the project.

Acknowledgements. We thank the crew of the R/V Western Arctic, the crew of SE-HLA, Ken Henderson of Exploration Consultants Ltd and Poul S. Hansen of Danish Hydraulic Institute for their cooperation in this project.

The project is funded by the European Economic Community (EEC) and by the Danish Ministry of Energy.

\section{References}

Larsen, H. C. 1980: Geological perspectives of the East Greenland continental margin. Bull. geol. Soc. Denmark, 29, 77-101.

Larsen, H. C. \& Jacobsen, N.: Palaeogene spreading along the northern Reykjanes Ridge: new evidence from offshore East Greenland (submitted to Earth planet. Sci. Lett.).

Larsen, H. C. \& Thorning, L. 1980: Project Eastmar: acquisition of high sensitivity aeromagnetic data off East Greenland. Rapp. Grønlands geol. Unders. 100, 91-94. 
Risum, J. B. 1980: Project Nad - Part 2: a marine geophysical project offshore East Greenland: Rapp. Grønlands geol. Unders. 100, 99-101.

Thorning, L. 1980: A system of computer programmes for the processing and interpretation of aeromagnetic data. Unpubl. int. GGU report, $58 \mathrm{pp}$.

\title{
Glaciological investigations at Qamanârssûp sermia, West Greenland
}

\author{
Ole B. Olesen
}

As part of the GGU programme for the regional mapping of the hydroelectric potential of West Greenland, glaciological investigations were started at the Qamanârssûp sermia in 1979. The glacier is situated at the innermost part of Godthåbsfjord (Kangersuneq) and is an outlet glacier from the Inland Ice proper, running west down to about $60 \mathrm{~m}$ above sea level. From the snout up to the $1500 \mathrm{~m}$ contour line the area has been measured to be $146 \mathrm{~km}^{2}$. Above this height the boundaries of the drainage area have not yet been adequately defined, so no area measurement has been attempted.

\section{Ablation measurements}

In 1979 and 1980 the work has concentrated on establishing a network of ablation stakes on the glacier. Due to the size and the rough surface of the glacier (including two impassable icefalls) this has been a difficult task, and only this summer has the stake network been extended to $1400 \mathrm{~m}$ above sea level.

As the glacier was bare of snow up to about $1000 \mathrm{~m}$, both during a visit in early March and at the start of the summer field season in early June, only ablation measurements have been carried out.

The net balance on the lower $1000 \mathrm{~m}$ of the glacier has been calculated to be $-215 \times 10^{6}$ $\mathrm{m}^{3}$ of water equivalent for the period 8 September 1979 to 21 September 1980 (fig. 21 and Table 6). The corresponding elevation of the firn line was just above $1300 \mathrm{~m}$ above sea level.

The recession on the net balance curve in fig. 21 , between $100-300 \mathrm{~m}$ is most probably due to shadow effects and frequent low fog coming in from the fjord.

\section{Other investigations}

In concert with the ablation measurements, meteorological observations were carried out both at the base camp and at the same elevation on the glacier. Temperature, humidity, evaporation, precipitation, wind run and direction, sunshine duration and cloud cover were 